\title{
COMPARISON OF PERIOPERATIVE, LONG-TERM COMPLICATIONS AND RECURRENCE RATES AFTER VAGINAL PROLAPSE SURGERY BY CONSIDERING ICS POP-Q STAGE
}

\author{
Yeon Soo Jung, MD¹, Soo Rim Kim, MD¹, Yeo Jung Moon, MD², Sei Kwang Kim, MD¹, Sang Wook Bai, MD¹ \\ Departments of ${ }^{1}$ Obstetrics and Gynecology, Institute of Women's Life Medical Science, ${ }^{2}$ Pharmacology, Yonsei University College of Medicine, Seoul, Korea
}

\section{Objective}

The aim of this study was to report subjective and objective outcomes and to compare complication and recurrence rate in patients undergoing surgery for International Continence Society (ICS) stage 4 prolapse compared to ICS stage 2 or 3 prolapse.

\section{Methods}

We retrospectively reviewed the records of all patients having had surgical treatment for ICS Pelvic Organ Prolapse Quantification (POP-Q) stage 2-4 prolapse between January 2007 and December 2010 at the Yonsei University Severance Hospital. Only patients with ICS POP-Q stage 2-4 prolpase undergoing obliterative procedures or anti-incontinence surgery only were excluded.

Results

Three hundred ninety nine patients met inclusion criteria, including 23 with stage 2, 239 with stage 3 and 137 with stage 4 prolapse. The postoperative recurrence rate of preoperative stage IV was 2.4 times higher than that of stage III. There was a significantly higher incidence rates of perioperative and long-term complications, compared to women with other stage prolapse. The mean operative time was significantly greater in the stage 4 group compared to the stage 2, 3 group.

\section{Conclusion}

The overall perioperative complication and recurrence rates in women undergoing surgery for pelvic organ prolapse are low. Women undergoing surgery for ICS POP-Q stage 4 prolapse were found to have a significantly greater blood loss and higher incidence rates of perioperative complications and recurrence, compared with women of other stage.

Keywords: Pelvic organ prolapse; Stage; Postoperative complication; Recurrence

Pelvic organ prolapse (POP) is a bulge or protrusion into or through the vagina of pelvic organs and associated vaginal segments [1]. With the aging population, POP is an increasingly common condition seen in women with a lifetime prevalence of $30 \%$ to $50 \%[1,2]$. Symptomatic urogenital prolapse has been shown to have significant negative impacts such as those relating to the lower urinary tract, fecal incontinence, back pain, pelvic pain, defecatory problems, and dyspareunia. Management options for women with symptomatic POP include observation, pelvic floor muscle training, mechanical support (pessaries), and surgery. A patient's perception of discomfort from POP and subsequent treatment will vary in relation to the stage of the POP and her ethnicity. Currently, many surgical approaches have been introduced to correct POP. The life time risk of undergoing surgery was estimated to be between $11 \%$ and $19 \%$. However, none of these techniques is without risks for complications [2-4]. The prevalence of reopera-

Received: 2012.3.15. Revised: 2012.4.30. Accepted: 2012.6.1. Corresponding author: Sang Wook Bai, MD Department of Obstetrics and Gynecology, Institute of Women's Life Medical Science, Yonsei University College of Medicine, CPO Box 8044, Sinchon-dong, Seodaemun-gu, Seoul 120-752, Korea Tel: +82-2-2228-2230 Fax: +82-2-313-8537

E-mail: swbai@yuhs.ac

This is an Open Access article distributed under the terms of the Creative Commons Attribution Non-Commercial License (http://creativecommons.org/licenses/ by-nc/3.0/) which permits unrestricted non-commercial use, distribution, and reproduction in any medium, provided the original work is properly cited.

Copyright (C) 2012. Korean Society of Obstetrics and Gynecology 


\section{KOREAN JOURNAL OF OBSTETRICS \& GYNECOLOGY}

Yeon Soo Jung, et al. Complications, recurrence, POP-Q stage

tion reported in some studies is high (43\% to $56 \%$ ) but probably overestimated as these studies included genital prolapse after Burch colposuspension $[5,6]$. Prevalence of reoperation for POP or urinary incontinence was $29.2 \%$ in a community-based population [2]. However data are lacking that compare perioperative, longterm complications and recurrence rates of other stage prolapse, and very little is known about the factors associated with surgical failure. The aim of this study was to report subjective and objective outcomes and to compare complication rates in patients undergoing surgery for International Continence Society (ICS) stage 4 prolapse compared to ICS stage 2, or 3 prolapse.

\section{Materials and Methods}

We retrospectively reviewed, using a computerized medical record database, all women $(n=399)$ who underwent surgical treatment for the for ICS Pelvic Organ Prolapse Quantification (POP-Q) stage 2-4 prolapse in the Department of Obstetrics and Gynecology, Division of Female Pelvic Medicine and Reconstructive Surgery, Yonsei University Health System (Seoul, Korea) between January 2007 and December 2010. All patients provided a detailed urogynecologic and medical history, and underwent a comprehensive physical examination including the grading of prolapse utilizing the ICS POP-Q staging system by the same examiner and multichannel urodynamic testing when indicated. The surgical technique and combination of procedures were chosen after informed consent from each patient, with the objective of correcting anatomic support of all prolapsed compartments. All procedures were performed by one senior surgeon. Patients with ICS POP-Q stage 2-4 prolpase undergoing obliterative procedures or antiincontinence surgery only were excluded. The study group was classified into 3 categories according to ICS POP-Q staging, 23 women with stage 2; 239 women with stage 3; and 137 women with stage 4 prolapse. The date and indication for POP surgery were collected, as well as the route of POP surgery (abdominal, vaginal or laparoscopic) and the use of prosthetic material. The surgical techniques used in our institution for abdominal and vaginal POP reconstruction were those described by Hirsch et al. Most of the procedures were conventional vaginal POP repairs without mesh, which were the techniques performed in our institution from 2005. Concomitant procedures such as urinary incontinence repair or hysterectomy were also identified. The patients who had had prolapse above stage 2 of the apical compartment were performed hysterectomy. Complications were subdivided into perioperative (within 2 month of the operation) and long-term (at least 2 month after the operation) complications. Perioperative and long-term complications, including estimated blood loss (EBL), blood transfusion, bladder injury, ureter injury, bowel injury, ureter obstruction, bowel obstruction, wound healing problem, urinary tract infection, urinary retention, urinary incontinence, voiding difficulty, mesh erosion, pelvic abscess, incisional hernia, and need to alter surgical procedure were evaluated. A blood loss $\geq 500$ $\mathrm{mL}$ was considered excessive. Patients were followed-up 1, 3, 6, and 12 months after surgery, and every year thereafter during the study period. At each visit, urinary/bowel symptoms and other problems were assessed. Changes in POP-Q stage and vaginal vault healing status were also examined. Data were reviewed on length of hospital stay, operation time, and difference between hemoglobin levels preoperatively and on the third postoperative day. Functional outcomes regarding urinary/bowel symptoms and anatomical recurrences were also assessed. Anatomical recurrence was defined as any prolapse equal to or greater than stage 2 of the POP-Q classification.

\section{Statistical analysis}

Data analyses were performed by another professional who was blinded to the group allocation and had no knowledge of the interpretation of the results. The SPSS ver. 18.0 (IBM Co., Armonk, New York, NY, USA) was used for the statistical analyses. Baseline categorical variables were analyzed using chi square or Fisher's exact test. Continuous variables were analyzed using the Wilcoxon rank sum test or the Krukal-Wallis test. A nominal two-sided $P$-value $<0.05$ was considered to indicate statistical significance.

\section{Results}

Three hundred ninety-nine patients met inclusion criteria, including $23(5.8 \%)$ with stage 2,239 (70.5\%) with stage 3, and 137 (34.3\%) with stage 4 prolapse. The median postoperative follow-up time was 31.6 months, ranging from 3 to 47 months. Patients with prolapse stage 4 group were older than those in the stage 2, 3 groups but there was no statistical significance (mean age \pm standard deviation [SD]: II, $62.6 \pm 8.3$ years; III, $63.4 \pm 9.9$ years; IV, $66.5 \pm 9.5$ years; $P=0.62$ ). Patients of stage 4 group who had given vaginal birth had more prolpase than early stage groups, but also there was no significant differences. There was no significant difference in body mass index (BMI) (mean BMI $\pm S D$, $24.5 \pm 3.2 \mathrm{~kg} / \mathrm{m}^{2}$ ), parity (mean parity, $3.3 \pm 1.4$ ), use of hormones 
23/399 (5.8\%), and menopause 366/399 (91.7\%) (Table 1).

The number of prior Cesarean section, hysterectomy and previous repair were similar among the three groups. The number of patients who underwent anterior colporrhaphy was 251 (II, 17 [73.9\%]; III, 170 [71.1\%]; IV, 64 [46.7\%]), posterior colporrhaphy (II, 21 [91.3\%]; III, 229 [95.8\%]; IV, 123 [89.8\%]), abdominal hysterectomy (II, 0 [0\%]; III, 33 [13.8\%]; IV, 44 [32.1\%]), vaginal hysterectomy (II, 2 [8.7\%]; III, 60 [25.1\%]; IV, 56 [40.9\%]), laparoscopic hysterectomy (II, 1 [4.4\%], III, 3 [1.3\%]; IV, 2 [1.5\%]), vaginal vault suspension (II, 1 [4.4\%]; III, 38 [15.9\%]; IV, 23 [16.8\%]), abdominal sacrocolpopexy (II, 3 [13.0\%]; III, 45 [18.8\%]; IV, $60[43.8 \%])$, paravaginal repair (II, 2 [8.7\%]; III, 34 [14.2\%]; IV, 7 [5.1\%]), midurethral sling (II, 11 [47.8\%]; III, 86 [36.0\%]; IV, 80 [58.4\%]) (Table 2). Both the mean EBL and the number of patients with blood loss $\geq 500 \mathrm{~mL}$ was significantly greater in the stage 4 group compared to the stage 2 , and 3 groups (mean \pm SD: II, $116.1 \pm 175.0 \mathrm{~mL} ; \mathrm{III}, 162.9 \pm 177.5 \mathrm{~mL} ; \mathrm{IV}, 224.4 \pm 177.6 \mathrm{~mL}$; $P<0.0001)$. The number of perioperative transfusions (II, $0 / 23[0 \%]$;

Table 1. Baseline characteristics

\begin{tabular}{|c|c|c|c|c|}
\hline Variable & Stage II $(n=23)$ & Stage III $(n=239)$ & Stage IV $(n=137)$ & $P$-value \\
\hline Age (yr) & $62.6 \pm 8.3$ & $63.4 \pm 9.9$ & $66.5 \pm 9.5$ & NS \\
\hline Body mass index $\left(\mathrm{kg} / \mathrm{m}^{2}\right)$ & $24.7 \pm 2.9$ & $24.5 \pm 2.9$ & $24.6 \pm 3.7$ & NS \\
\hline Parity & $3.2 \pm 1.1$ & $3.2 \pm 1.4$ & $3.6 \pm 1.5$ & NS \\
\hline Vaginal delivery & $3.2 \pm 1.2$ & $3.3 \pm 1.4$ & $3.6 \pm 1.6$ & NS \\
\hline Menopause & 23 & 213 & 130 & NS \\
\hline Hormone replacement therapy & 2 & 15 & 7 & NS \\
\hline Prior Cesarean section & 6 & 32 & 14 & NS \\
\hline Prioir hysterectomy & 5 & 23 & 21 & NS \\
\hline Prior pelvic reconstruction surgery & 3 & 19 & 11 & NS \\
\hline
\end{tabular}

Values are presented as mean \pm standard deviation or number (\%).

NS, not significant.

Table 2. Summary of surgical procedure

\begin{tabular}{|c|c|c|c|c|}
\hline Procedure & Stage II & Stage III & Stage IV & $P$-value \\
\hline \multicolumn{5}{|l|}{ Colporrhaphy } \\
\hline Anterior compartment & $17(73.9)$ & $170(71.1)$ & $64(46.7)$ & $<0.0001$ \\
\hline Posterior compartment & $21(91.3)$ & $229(95.8)$ & $123(89.8)$ & NS \\
\hline Paravaginal repair & $2(8.7)$ & $34(14.2)$ & $7(5.1)$ & 0.0220 \\
\hline \multicolumn{5}{|l|}{ Hysterectomy } \\
\hline Abdominal & $0(0)$ & $33(13.8)$ & $44(32.1)$ & $<0.0001$ \\
\hline Vaginal & $2(8.7)$ & $60(25.1)$ & $56(40.9)$ & 0.0004 \\
\hline Laparoscopic & $1(4.4)$ & $3(1.3)$ & $4(1.5)$ & NS \\
\hline \multicolumn{5}{|l|}{ The apical compartment } \\
\hline Sacrocolpopexy & $3(13.0)$ & $45(18.8)$ & $60(43.8)$ & $<0.0001$ \\
\hline Vaginal vault suspension ${ }^{a}$ & $1(4.4)$ & $38(15.9)$ & $23(16.8)$ & NS \\
\hline Incontinence procedure ${ }^{b}$ & $11(47.8)$ & $86(36.0)$ & $80(58.4)$ & 0.0001 \\
\hline \multicolumn{5}{|l|}{ Others } \\
\hline Bilateral salpingo-oophorectomy & $1(4.4)$ & $32(13.4)$ & $49(35.8)$ & $<0.0001$ \\
\hline Perineorrhaphy & $22(95.7)$ & $220(92.1)$ & $130(94.9)$ & NS \\
\hline
\end{tabular}

Values are presented as number (\%).

NS, not significant.

a Vaginal vault suspension included uterosacral vault suspension, sacrospinous vault suspension, and iliococcygeus vault suspension; ' ${ }^{b}$ ncontinence procedure included mid urethral slings (TVT, Sparc) and transobturator slings (Monarc). 


\section{KOREAN JOURNAL OF OBSTETRICS \& GYNECOLOGY}

Yeon Soo Jung, et al. Complications, recurrence, POP-Q stage

III, 2/239 [0.8\%]; IV, 6/137 [4.4\%]) was similar among the three groups. The mean operative time was significantly greater in the stage 4 group compared to the stage 2 , and 3 groups (mean \pm SD: II, $84.7 \pm 46.8$ minutes; III, $111.2 \pm 66.2$ minutes; IV, $146.4 \pm 58.4$ minutes; $P<0.0001$ ) (Table 3 ).

We evaluated 12 provisions of perioperative complications and 6 of long-term complications. The incidences of perioperative and long-term complications are presented in Table 4. The overall complications in women undergoing surgery for POP were rare; most of them were transient and reversible. Two bladder injuries occurred in the stage 3 group from anterior and posterior colporrhaphy, abdominal sacrocolpopexy and transobturator tape (TOT) midurethral sling; one bladder injury occurred in the stage 4 group from posterior colporrhaphy, abdominal sacrocolpopexy and TOT midurethral sling; and one ureter injury occurred in the stage 4 group from anterior and posterior colporrhaphy, vaginal hysterectomy, and TOT midurethral sling. There was a significantly higher incidence rate of perioperative and long-term complica-

Table 3. Perioperative parameters and complications

\begin{tabular}{|c|c|c|c|c|}
\hline Parameters & Stage II $(n=23)$ & Stage III $(n=239)$ & Stage IV $(n=137)$ & $P$-value \\
\hline Operation time (min) & $84.7 \pm 46.8$ & $111.2 \pm 66.2$ & $146.4 \pm 58.4$ & $<0.0001$ \\
\hline Estimated blood loss (mL) & $116.1 \pm 175.0$ & $162.9 \pm 177.5$ & $224.4 \pm 177.6$ & $<0.0001$ \\
\hline Difference between hemoblogin levels ( $\mathrm{g} / \mathrm{dL}$ ) & $1.6 \pm 0.7$ & $1.8 \pm 0.9$ & $1.9 \pm 1.1$ & NS \\
\hline Blood transfusion & $0(0)$ & $2(0.8)$ & $6(4.4)$ & NS \\
\hline Hospital stay (day) & $6.6 \pm 1.4$ & $7.1 \pm 2.4$ & $7.4 \pm 2.1$ & 0.0195 \\
\hline Complications & $1(4.3)$ & $12(5.0)$ & $18(13.1)$ & 0.015 \\
\hline
\end{tabular}

Values are presented as mean \pm standard deviation or number (\%).

NS, not significant.

Table 4. Perioperative, long-term complications and recurrence rates after vaginal prolapse surgery

\begin{tabular}{|c|c|c|c|}
\hline Complication & Stage II $(n=23)$ & Stage III $(n=239)$ & Stage IV $(n=137)$ \\
\hline \multicolumn{4}{|l|}{ Perioperative (<2 mo) } \\
\hline Blood transfusion & $0(0)$ & $2(0.8)$ & $6(4.4)$ \\
\hline Bladder injury & 0 & 2 & 1 \\
\hline Ureter injury & 0 & 0 & 1 \\
\hline Bowel injury & 0 & 0 & 1 \\
\hline Ureter obstruction & 0 & 0 & 1 \\
\hline Bowel obstruction & 0 & 2 & 2 \\
\hline Urinary retention & 1 & 1 & 2 \\
\hline Urinary incontinence & 0 & 1 & 3 \\
\hline Urinary tract infection & 0 & 1 & 2 \\
\hline Wound healing problem & 0 & 0 & 4 \\
\hline Mesh erosion & 0 & 1 & 0 \\
\hline Incisional hernia & 0 & 0 & 0 \\
\hline \multicolumn{4}{|l|}{ Long-term ( $\geq 2$ mo) } \\
\hline Urinary urgency & 0 & 1 & 3 \\
\hline Urinary incontinence & 0 & 1 & 3 \\
\hline Voiding dysfunction & 0 & 0 & 1 \\
\hline Wound healing problem & 1 & 1 & 0 \\
\hline Incisional hernia & 0 & 0 & 1 \\
\hline Recurrence & $1(4.3)$ & $9(3.8)$ & $13(9.5)$ \\
\hline
\end{tabular}

Values are presented as number (\%). 
tions, compared to women with other stage prolapse (perioperative complications: II, 1 [4.3\%]; III, 5 [2.1\%]; IV, 12 [8.8\%]; $P=0.010$; long-term complications: II, 1 [4.3\%]; III, 3 [1.3\%]; IV, 8 [5.8\%]; $P=0.040)$. There was no significant difference in recurrence rates among the three groups (II, 1 [4.3\%]; III, 9 [3.3\%]; IV, 13 [9.3\%]). However the postoperative recurrence rate of preoperative stage 4 was 2.4 times higher than that of stage 3 , which was statistically significant $(P=0.02287)$.

Regarding the access, the patients were operated on through various approaches; however there was no statistically significant difference according to the type of surgical approach. Hysterectomy (vaginal, abdominal, and laparoscopic) or surgery for the apical compartment (sacrocolpopexy, vaginal vault suspension) did not increase operation time, or the risk of greater blood loss (mean \pm SD; operation time: hysterectomy [201 women],
$145.9 \pm 55.6$ minutes; no hysterectomy [198 women], $97.2 \pm 65.4$ minutes; surgery for apical compartment prolapse [170 women],155.2 \pm 75.4 minutes; no surgery for apical compartment prolapse [229 women], 97.1 \pm 42.4 minutes; EBL: hysterectomy, $217.6 \pm 181.0 \mathrm{~mL}$; no hysterectomy, $144.4 \pm 171.7 \mathrm{~mL}$; surgery for apical compartment prolapsed, $306.0 \pm 168.7 \mathrm{~mL}$; no surgery for apical compartment prolapsed, $88.7 \pm 123.6 \mathrm{~mL}$ ) (Figs. 1, 2). History of abdominal operation or surgery for POP were also not associated with a higher risk of blood loss and longer operation time (mean $\pm S D$; operation time: prior abdominal operation history [52 women], $114.3 \pm 60.6$ minutes; no prior abdominal operation history [347 women], $122.4 \pm 65.8$ minutes; prior pelvic reconstruction (33 women), 130.1 \pm 80.5 minutes; no prior pelvic reconstruction (366 women), $121.0 \pm 63.8$ minutes; EBL: prior abdominal operation history, $127.6 \pm 185.9 \mathrm{~mL}$; no prior abdominal
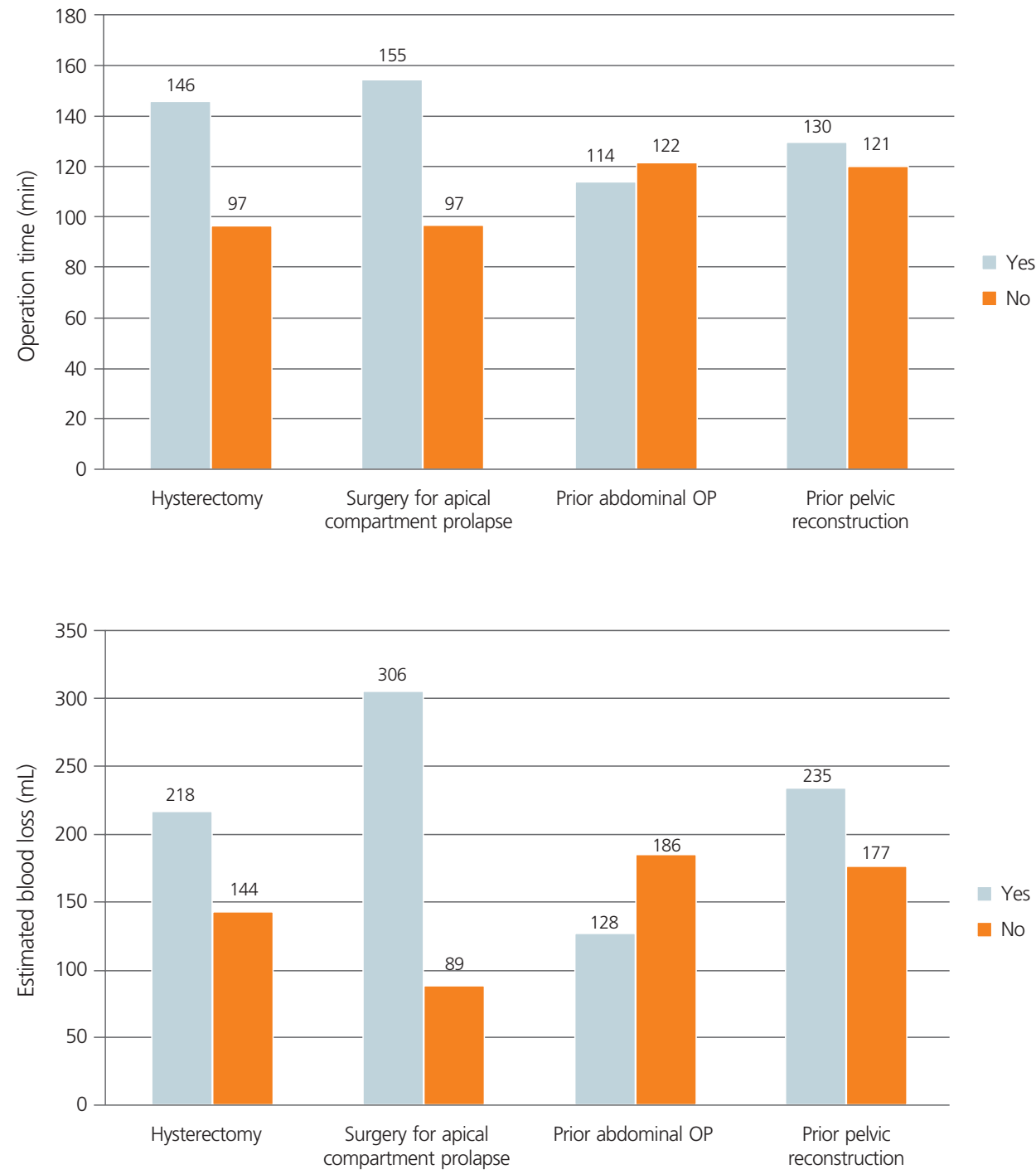

Fig. 1. Comparison of operation time according to the types of surgical approach and operation history. OP, operation.
Fig. 2. Comparison estimated blood loss according to the types of surgical approach and operation history. OP, operation. 


\section{KOREAN JOURNAL OF OBSTETRICS \& GYNECOLOGY}

Yeon Soo Jung, et al. Complications, recurrence, POP-Q stage

operation history, $186.0 \pm 179.1 \mathrm{~mL}$; prior pelvic reconstruction, $234.5 \pm 205.6 \mathrm{~mL}$; no prior pelvic reconstruction, $176.5 \pm 177.1$ $\mathrm{mL}$ ) (Figs. 1, 2). There was no statistically significant difference according to the prior abdominal operation history and pelvic reconstruction. Figs. 1, 2 demonstrate direct comparisons among three groups.

\section{Discussion}

In this study, we revealed that the POP-Q stage was the sole independent risk factor for the complications after standard restorative pelvic reconstructive surgery. However, there is little knowledge of the risk factors preventing or promoting complications, recurrence, and consecutive reoperation [7]. Data arise from a few studies with few identified risk factors [7]. According to the previous studies, younger age, preoperative advanced stage, traumatic delivery, urinary incontinence, and previous pelvic reconstructive surgery are suggested as the risk factors for recurrence [8-11]. Whiteside et al. [9] studied 176 patients out of 389 who were observed for a year after vaginal reconstructive surgery to find that younger age ( $<60$ years) was an important factor. A similar result was presented by Nieminen et al. [11], who evaluated the risk factors of recurrence in patients who received sacrospinous ligament fixation. Diez-Itza et al. [12] suggested that younger women and women with a higher body weight are more likely to experience recurrent prolapse after vaginal repair with 228 women, (for 5-year followup after surgery), while Nam et al. [13] suggested that obesity was a protective factor against blood loss and transfusion, and long-term urinary retention, diminished reserve could have been related to an adverse result. Prolapsed patients of a younger age were suspected of having a more pronounced tendency to present pathophysiology such as inferior tissue quality, and greater nerve, muscle, and fascial injury; but from another point of view, older patients were restricted from activity due to underlying medical problems [14].

The advanced preoperative stage (POP-Q stage III or IV) was another risk factor, as seen in the study of Whiteside et al. [9]. Vakili et al. [10] reported that diminished levator ani and widened genital hiatus were related to the recurrent prolapse through a median 5-month follow-up in 451 patients who received pelvic reconstructive surgery. Increasing size of genital hiatus is related to more advanced POP; this, too, shows that a preoperative advanced stage could result in recurrences [15]. Of 360 women who underwent POP surgery, Salvatore et al. [16] demonstrated that 36 women
(10\%) had a recurrent prolapse, and a preoperative vaginal descent (more than stage 3) was the only significant risk factor, which is similar to our results. In our study, preoperative POP-Q stage 3 recurred more than stage 2 did, but the difference was not statistically significant. However, the postoperative recurrence rate of preoperative stage 4 was 2.4 times higher than that of stage 3 , which was statistically significant. In Tegerstedt and Hammarstrom [8]'s study, univariate analysis showed that prolapsed stage 4 adversely affects the outcome on both symptomatic and anatomic recurrence, but not on the anatomic recurrence alone. This could be the result of the selection bias of this research, in which $138(53 \%)$ out of 269 patients who received operations were excluded from follow-up loss. In addition, difference in degrees of preoperative prolapse between the patients who were followed up and those who were not (most of the patients with advanced preoperative stage of prolapse were lost during the follow-up) [14]. Nieminen et al. [11] also concluded that the degree of preoperative prolapse had little to do with the recurrence. Also, Tegerstedt and Hammarstrom [8] reported complicated delivery, urinary incontinence, and prior pelvic floor surgery to be the independent risk factors of recurrence, in contrast to the results by Nieminen et al. [11], Whiteside et al. [9] or our study. This could be explained by the fact that the study by Tegerstedt and Hammarstrom [8], as mentioned above, had a relatively longer follow-up period of 10 to 12 years; (although many patients were lost during the followup) [14].

History of surgery for POP and/or urinary incontinence at the time of primary surgery was associated with an increased postoperative complications and risk of reoperation in two studies $[17,18]$. According to Maher et al. [19], there were insufficient data to allow evaluation of the impact of prolapsed surgery on continence issues. However, limited information suggested that concomitant TVT or Burch colposuspension might reduce postoperative incontinence rates; this benefit needs to be balanced against possible differences in costs and adverse effects. Clark et al. [17] demonstrated that having undergone previous POP and urinary incontinence surgery increased the risk of reoperation to $17 \%$ compared with $12 \%$ for women who underwent a first procedure; moreover Denman et al. [18] observed the abdominal approach was protective against reoperation compared with the vaginal approach. Dällenbach et al. [7] suggested that POP severity did not increase the risk of complications and reoperation, and that neither did advancing age, BMI and vaginal deliveries, but suggested that the number of prolapsed vaginal wall segments and the absence of complete repair at initial surgery increased the risk of reoperation. 
It is nowadays widely accepted that underlying connective abnormalities, (in addition to hereditary factors), predispose to POP, and our study shows that they also predispose to POP recurrence [2023].

Nevertheless, we found that POP severity, expressed most distal preoperative POP stage, was associated with a significantly greater blood loss, and higher incidence rates of perioperative and long-term complications. Although the exact reason was not clear in the present study, we suggest that the risk of complication after POP surgery is associated with variables indicating preexisting weakness of pelvic floor tissues.

Surgically treated prolapse represents the severe end of the spectrum of POP. The anatomical recurrence rate in our cohort is probably lower, at 30 women (7.5\%); in most cases, women are asymptomatic and do not require surgery, 2 women (6.7\%) among them underwent reoperation. In a cohort of 389 women who underwent POP vaginal repair, recurrence (stage 2 or more) was observed in $58 \%$ of the women after one year only [9]. However, only $9.7 \%$ had prolapsed protruding beyond the hymen. In another study, anatomical failure (vaginal wall prolapsed stage 2 or more) was $31.3 \%$, but only $7.4 \%$ had POP related symptoms [12].

We found significant lower rate of major complications requiring readmission or reoperation, which may be partly due to minimal use of mesh and the use of appropriate mesh; that is, ultralightweight polypropylene mesh.

Mesh complications such as chronic pelvic pain often happen with more serious and challenging problems, without any easy answer. Another factor is the technique for vaginal dissection. In this study, special concern was taken to achieve full-thickness dissection of the vaginal compartments after hydrodissection. This preserves the epithelial blood supply, and fully covers the mesh implant, which may influence mesh exposure. The role of vaginal dissection has to be assessed by further studies.

The strength of this study was that it compared POP-Q stage including grade 2 with the incidence of perioperative complications and recurrence in women undergoing initial surgery for POP. In addition, the availability of a continuously updated computerized register, allowed us to identify cases and controls in the same large cohort with a long follow-up. More long-term studies that directly compare these three groups are required to support these findings definitively.

The findings of this study may have been limited by several factors. The major weaknesses of this study were that it was retrospective in nature and had a small sample size. However, the percentage of follow-up loss was low (0\%) compared with those of other studies. No patients were excluded from the analysis because records were not available or risk factors missing. We used the standardized POP-Q system for the evaluation of prolapse and thoroughly investigated pelvic floor dysfunction and its complication. It is recommended that severity of prolapse take into account not only the stage of the most distal end but also the number of compartments involved. However, our study did not consider the preoperative POP substage and the number of prolapsed vaginal segments. Moreover, the overall perioperative complications and recurrence in women undergoing surgery for POP were rare (most were transient and reversible) and varied. Our own cohort was too small to draw any conclusion. We studied only distributions of complications. Finally, the impact of surgery on associated pelvic floor symptoms including bladder, bowel and sexual function, quality of life issues such as dyspareunia and patient satisfaction, cost, were not examined.

Additional prospective studies are needed to assess the effect of surgery in subgroups of women with different clinical and demographic characteristics. Large population-based long-term followup studies on pelvic floor dysfunction are needed in the future to draw a more definite conclusion.

\section{References}

1. Holschneider CH, Berek JS. Valvar cancer. In: Berek JS, Novak E. Berek \& Novak's gynecology. 14th ed. Philadelphia (PA): Lippincott Williams \& Wilkins; 2007. p.897-934.

2. Olsen AL, Smith VJ, Bergstrom JO, Colling JC, Clark AL. Epidemiology of surgically managed pelvic organ prolapse and urinary incontinence. Obstet Gynecol 1997;89:501-6.

3. Fialkow MF, Newton KM, Lentz GM, Weiss NS. Lifetime risk of surgical management for pelvic organ prolapse or urinary incontinence. Int Urogynecol J Pelvic Floor Dysfunct 2008;19:437-40.

4. Smith FJ, Holman CD, Moorin RE, Tsokos N. Lifetime risk of undergoing surgery for pelvic organ prolapse. Obstet Gynecol 2010;116:1096-100.

5. Boyles SH, Weber AM, Meyn L. Procedures for urinary incontinence in the United States, 1979-1997. Am J Obstet Gynecol 2003:189:70-5.

6. Luber KM, Boero S, Choe JY. The demographics of pelvic floor disorders: current observations and future projections. Am J Obstet Gynecol 2001;184:1496-501. 


\section{KOREAN JOURNAL OF OBSTETRICS \& GYNECOLOGY}

Yeon Soo Jung, et al. Complications, recurrence, POP-Q stage

7. Dällenbach P, Jungo Nancoz C, Eperon I, Dubuisson JB, Boulvain $\mathrm{M}$. Incidence and risk factors for reoperation of surgically treated pelvic organ prolapse. Int Urogynecol J 2012;23:3541.

8. Tegerstedt G, Hammarström M. Operation for pelvic organ prolapse: a follow-up study. Acta Obstet Gynecol Scand 2004;83:758-63.

9. Whiteside JL, Weber AM, Meyn LA, Walters MD. Risk factors for prolapse recurrence after vaginal repair. Am J Obstet Gynecol 2004;191:1533-8.

10. Vakili B, Zheng YT, Loesch H, Echols KT, Franco N, Chesson RR. Levator contraction strength and genital hiatus as risk factors for recurrent pelvic organ prolapse. Am J Obstet Gynecol 2005;192:1592-8.

11. Nieminen $K$, Huhtala $H$, Heinonen PK. Anatomic and functional assessment and risk factors of recurrent prolapse after vaginal sacrospinous fixation. Acta Obstet Gynecol Scand 2003;82:471-8.

12. Diez-Itza I, Aizpitarte I, Becerro A. Risk factors for the recurrence of pelvic organ prolapse after vaginal surgery: a review at 5 years after surgery. Int Urogynecol J Pelvic Floor Dysfunct 2007;18:1317-24.

13. Nam KH, Jeon MJ, Hur HW, Kim SK, Bai SW. Perioperative and long-term complications among obese women undergoing vaginal surgery. Int J Gynaecol Obstet 2010;108:244-6.

14. Jeon MJ, Chung SM, Jung HJ, Kim SK, Bai SW. Risk factors for the recurrence of pelvic organ prolapse. Gynecol Obstet Invest 2008;66:268-73.

15. Delancey JO, Hurd WW. Size of the urogenital hiatus in the levator ani muscles in normal women and women with pelvic organ prolapse. Obstet Gynecol 1998;91:364-8.

16. Salvatore $S$, Athanasiou S, Digesu GA, Soligo M, Sotiropoulou $M$, Serati $M$, et al. Identification of risk factors for genital prolapse recurrence. Neurourol Urodyn 2009;28:301-4.

17. Clark AL, Gregory T, Smith VJ, Edwards R. Epidemiologic evaluation of reoperation for surgically treated pelvic organ prolapse and urinary incontinence. Am J Obstet Gynecol 2003;189:1261-7.

18. Denman MA, Gregory WT, Boyles SH, Smith V, Edwards SR, Clark AL. Reoperation 10 years after surgically managed pelvic organ prolapse and urinary incontinence. Am J Obstet Gynecol 2008;198:555.e1-5.

19. Maher C, Baessler K, Glazener CM, Adams EJ, Hagen S. Surgical management of pelvic organ prolapse in women: a short version Cochrane review. Neurourol Urodyn 2008;27:3-12.

20. Buchsbaum GM, Duecy EE, Kerr LA, Huang LS, Perevich M, Guzick DS. Pelvic organ prolapse in nulliparous women and their parous sisters. Obstet Gynecol 2006;108:1388-93.

21. Jack GS, Nikolova G, Vilain E, Raz S, Rodríguez LV. Familial transmission of genitovaginal prolapse. Int Urogynecol J Pelvic Floor Dysfunct 2006;17:498-501.

22. Moalli PA, Shand SH, Zyczynski HM, Gordy SC, Meyn LA. Remodeling of vaginal connective tissue in patients with prolapse. Obstet Gynecol 2005;106:953-63.

23. Norton PA, Baker JE, Sharp HC, Warenski JC. Genitourinary prolapse and joint hypermobility in women. Obstet Gynecol 1995;85:225-8. 


\section{골반장기탈출증의 각 병기에 따른 수술 후 합병증 및 재발률 비교}

\section{연세대학교 의과대학 ${ }^{1}$ 산부인과학교실, ${ }^{2}$ 약리학교실}

정연수 ${ }^{1}$, 김수림 ${ }^{1}$, 문여정 ${ }^{2}$, 김세광 ${ }^{1}$, 배상욱 $^{1}$

\section{목적}

본 연구는 골반장기탈출증 환자에서 병기가 증가함에 따라 수술 후 합병증과 재발률이 증가하는지에 대해 알아보고자 하였다.

\section{연구방법}

2007년 1월부터 2010년 12월까지 본원 산부인과에서 골반장기탈출증으로 수술을 시행받은 국제요실금학회 골반장기탈출증 2기에서 4 기까지의 환자 중 기록분석이 가능한 399명의 환자를 대상으로 하였다. 골반장기탈출증 2 기에서 4 기까지 각 병기에 따른 환자들의 특성 과 재원일수, 신체질량지수, 기왕 수술력, 수술시간, 수술방법, 기저 질환, 수술 전·후의 혈색소 차이와 수술 후 합병증, 재발률에 대해 후향 적으로 조사하여 비교 분석하였다.

\section{결과}

총 399명 중 2기 23명(5.8\%), 3기 239명(70.5\%), 4기 137명(34.3\%)으로 병기가 높을수록 연령과 질식분만이 증가하였으나 통계학적으로 유의한 상관관계는 보이지 않았다. 각 환자군에서 신체질량지수, 호르몬 치료 여부, 폐경 여부, 이전의 제왕절개술 및 수술력의 차이는 없 었다. 골반장기탈출증 4기 환자군에서 2, 3기 환자군에 비해 수술 후 합병증 발생이 유의하게 높았고(2개월 이내: 2기, 1명[4.3\%]; 3기, 5 명[2.1\%]; 4기, 12명[8.8\%]; $P=0.010 ; 2$ 개월 이후: 2기 1명[4.3\%], 3기 8명[3.3\%], 4기 13명[9.5\%]; $P=0.041)$, 평균 수술시간 또한 병기

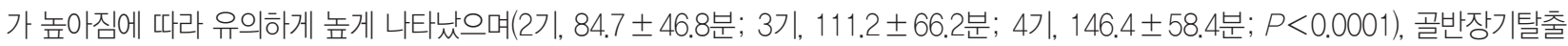
증 3기, 4 기 환자군에서 재발률에 유의한 차이를 보였다(3기, 9 명[3.8\%]; 4 기, 13 명[9.5\%]; $P=0.023$ ). 수술 전후의 혈색소 차이와 수혈은 통계학적으로 유의한 상관 관계가 없었다.

\section{결론}

골반장기탈출증 환자에서 병기가 증가함에 따라 수술 후 합병증 및 재발률이 증가하는 것으로 생각된다.

중심단어: 골반장기탈출증, 골반장기탈출증 병기, 수술 후 합병증, 재발률 